\title{
Effect of influenza A virus infection on acid-induced cough response in children with asthma
}

\author{
T. Shimizu, H. Mochizuki, A. Morikawa
}

\begin{abstract}
Effect of influenza A virus infection on acid-induced cough response in children with asthma. T. Shimizu, H. Mochizuki, A. Morikawa. @ERS Journals Ltd 1997.

ABSTRACT: Although it is well-known that some types of respiratory viral infections cause airway hyperresponsiveness in humans, the effect of viral infection on the cough threshold in asthmatics is not known. We, therefore, evaluated the effects of naturally-acquired influenza A virus infection on the cough threshold to inhaled acid in children with asthma.

Twelve children with asthma ( 9 boys and 3 girls, mean \pm SEM age of $10.8 \pm 0.6$ yrs), who had naturally-acquired influenza A virus infection in winter (January-February, 1992) during an epidemic of influenza $A\left(H_{1} N_{1}\right)$, were enrolled in this prospective, uncontrolled study. All patients underwent acetic acid (AA) inhalation challenge 2,4 and 6 weeks after the influenza infection.

The cough threshold values (the lowest concentrations of AA eliciting coughs) after 2,4 and 6 weeks of the illness were $3.7 \pm 0.9,5.3 \pm 1.0$ and $8.1 \pm 1.4 \%$ (mean \pm SEM), respectively. Cough threshold values 4 or 6 weeks after the illness improved significantly over that at 2 weeks $(p<0.05$ and $p<0.01$, respectively). In contrast, baseline forced expiratory volume in one second did not change throughout the study.

These results indicate that influenza A virus infection attenuates the cough threshold independently of airway obstruction in children with asthma. The enhanced cough response following virus infection is probably mediated by damage to the airways epithelium.
\end{abstract}

Eur Respir J., 1997; 10: 71-74.
Dept of Pediatrics, Gunma University, School of Medicine, Maebashi, Gunma 371, Japan.

\author{
Correspondence: T. Shimizu \\ Dept of Pediatrics \\ Gunma University School of Medicine \\ 3-39-22 Showa-machi \\ Maebashi \\ Gunma 371 \\ Japan
}

\section{Keywords: Asthma \\ cough}

viral infection

Received: April 21996

Accepted after revision September 151996
It is well-known that some types of viral and mycoplasma infections in the airways exacerbate asthma, especially in children [1-6]. Previous studies have shown that viral and mycoplasma infections cause bronchial hyperresponsiveness and small airway dysfunction [711]. In contrast, less is known about the effect of viral infection on the cough threshold. In the paediatric field, cough is one of the most common symptoms associated with respiratory disease, and is sometimes the only important symptom in childhood asthma. As far as we know, only EMPEY et al. [7] have reported that adult nonasthmatic subjects with colds showed a lowered cough threshold to inhaled acid.

In the present study, we examined the effect of naturally acquired influenza A infection on the cough threshold to inhaled acid in children with asthma.

\section{Materials and methods}

\section{Subjects}

Twelve children with asthma ( 9 boys and 3 girls, mean \pm SEM age $10.8 \pm 0.6 \mathrm{yrs}$ ), who had naturally acquired influenza A virus infections in winter (January-February, 1992) during an epidemic of influenza $A\left(\mathrm{H}_{1} \mathrm{~N}_{1}\right)$, were enrolled in this study. They were all in-patients at the time of the study, who had been institutionalized for long periods for the control of asthma. The clinical diagnosis of bronchial asthma was based on a characteristic history of recurrent attacks of dyspnoea with perceptible wheezing. The diagnosis was made after more than 1 year of follow-up. Almost all the patients reacted to the causative allergens in the skin-prick test and/or in the radioallergosorbent test (RAST) (development of a wheal $5 \mathrm{~mm}$ or larger in a skin-prick test and more than 0.70 Phadebas RAST units (PRU). None of the patients required oral corticosteroid administration. The characteristics of the study patients are presented in table 1 .

All the patients had been free from upper respiratory tract infections for at least 8 weeks before the study, and showed typical symptoms of influenza infection (rhinorrhoea, sore throat and fever) during the acute phase. The diagnosis of influenza A virus infection was confirmed by a significant rise (fourfold or greater) in serum complement fixation antibody titre to influenza A virus in paired sera obtained during the acute and convalescent phases. The day when a patient had a temperature of more than $37.5^{\circ} \mathrm{C}$ for the first time was regarded as the first day of illness. Treatment with medications was kept constant before and throughout the study, except for temporary beta ${ }_{2}$-adrenergic agonist inhalation and oral mefenamic acid administration in the acute phase. 
Table 1. - Characteristics of the study patients

\begin{tabular}{cccccll}
\hline $\begin{array}{l}\text { Ss } \\
\text { No. }\end{array}$ & Sex & $\begin{array}{c}\text { Age } \\
\text { yrs }\end{array}$ & $\begin{array}{c}\text { Duration* } \\
\text { yrs }\end{array}$ & $\begin{array}{c}\text { Total IgE } \\
\text { IU·mL }-1\end{array}$ & Allergens & Treatment \\
\hline 1 & M & 13 & 4 & 282 & Mite, cat & DSCG, T, B \\
2 & M & 13 & 10 & 884 & Mite & DSCG, T \\
3 & M & 13 & 5 & 1531 & Mite & DSCG, T, B \\
4 & M & 12 & 9 & 2000 & Mite, mould & DSCG, T, B, BDI \\
5 & M & 12 & 11 & 1936 & Mite & DSCG, T, B \\
6 & F & 12 & 9 & 1100 & Mite & DSCG, T \\
7 & M & 11 & 10 & 2000 & Mite & DSCG, T \\
8 & M & 10 & 9 & 75 & - & DSCG, T, B, BDI \\
9 & F & 10 & 5 & 956 & Mite, cat & DSCG, T, B \\
10 & M & 8 & 6 & 1970 & Mite & DSCG, T, B \\
11 & M & 8 & 6 & 35 & - & DSCG, T, B, BDI \\
12 & F & 8 & 7 & 253 & Mite & DSCG, T, B \\
\hline
\end{tabular}

*: duration of asthma symptoms; Ss: subjects; M: male; F: female; IgE: immunoglobulin E; DSCG: disodium cromoglycate inhalation; T: theophylline preparation; $\mathrm{B}$ : beta -adrenergic $^{-}$ agonist preparation; BDI: beclomethasone dipropionate inhalation.

\section{Experimental protocol}

All the patients underwent acetic acid (AA) inhalation challenge to determine the cough threshold 2, 4 and 6 weeks after influenza infection. Spirometry was performed before each AA inhalation challenge using an electronic spirometer (Chest M.I. Co., Tokyo, Japan) to check the airway condition. The patients were not symptomatic at the time of the inhalation challenge and showed a baseline forced expiratory volume in one second (FEV1) greater than $70 \%$ of the value predicted for their age [12].

Informed consent for the study was obtained from the patients and their parents before the examination. The study was approved by the Ethics Committee of the hospital.

\section{Acetic acid (AA) inhalation challenge}

The procedure of AA inhalation challenge has been described previously $[13,14]$ and was similar to that of Mitsuhashi and co-workers [15, 16], which has good reproducibility. Briefly, AA solution was prepared on the same day and diluted twofold with $0.9 \%$ saline solution (concentration $0.04-20 \%$; pH; 3.13-1.62; osmolarity; 292-1,113 $\mathrm{mOsm} \cdot \mathrm{kg}^{-1}$ ), and administered via a DeVilbiss model 646 nebulizer (DeVilbiss Co., Somerset, Pa, USA) with a constant airflow of $5 \mathrm{~L} \cdot \mathrm{min}^{-1}$. The output of the nebulizer was $0.15 \pm 0.01 \mathrm{~mL} \cdot \mathrm{min}^{-1}$. The FEV1 was measured just before and after each inhalation challenge. After administration of a local anaesthesia to the nasopharynx by procaine swabbing, the subjects wore a noseclip and inhaled the aerosol by tidal breathing for $10 \mathrm{~s}$. An aerosol of normal saline solution was inhaled first, followed by twofold increasing concentrations of AA (from 0.04 to $20 \%$ ) until a first cough was induced, as recognized by more than two independent observers, or until the highest concentration was reached. It was agreed that the percentage of the AA concentration inducing the first cough would be considered to be the threshold of hyperresponsiveness of cough receptors. Medications were stopped at least $12 \mathrm{~h}$ prior to each AA inhalation challenge.

\section{Statistical analysis}

Nonparametric analysis of variance (Friedman's twoway ANOVA) was used to determine the significance of variance between groups. If a significant variance was found, a Wilcoxon's matched-pairs signed ranks test was performed to assess the difference between individual groups. A p-value of less than 0.05 was considered to be significant.

\section{Results}

Eight of the 12 study patients $(67 \%)$ had mild asthmatic attacks (presence of wheeze and transient fall in peak expiratory flow rate) which were controlled with the timely use of an inhaled beta ${ }_{2}$-adrenergic agonist in the acute phase of illness. None of the study patients was symptomatic 2, 4 or 6 weeks after the disease onset. Spirometric values, including baseline FEV1, were unchanged throughout the study (table 2).

In contrast, changes in the cough threshold values to inhaled AA seemed to be present both in patients with and without asthmatic attack. Seven of 8 patients with attack and 2 of 4 patients without attack changed their cough threshold values to inhaled AA during the study. The cough threshold values (mean \pm SEM) in all the patients 2,4 and 6 weeks after disease onset were $3.7 \pm 0.9,5.3 \pm 1.0$ and $8.1 \pm 1.4 \%$, respectively. The values 4 or 6 weeks after the virus infection were significantly improved over those at 2 weeks ( $\mathrm{p}<0.05$ and $\mathrm{p}<0.01$, respectively) (fig. 1).

Table 2. - Spirometric values at 2, 4 and 6 weeks after the influenza infection

\begin{tabular}{lccc}
\hline & \multicolumn{3}{c}{ Postinfection time } \\
\cline { 2 - 4 } & 2 weeks & 4 weeks & 6 weeks \\
\hline FVC L & $2.35 \pm 0.20$ & $2.43 \pm 0.20$ & $2.38 \pm 0.20$ \\
FEV1 L & $1.96 \pm 0.18$ & $1.93 \pm 0.20$ & $2.02 \pm 0.18$ \\
PEF L $\cdot \mathrm{s}^{-1}$ & $3.56 \pm 0.37$ & $3.59 \pm 0.38$ & $3.74 \pm 0.32$ \\
MMF L L s ${ }^{-1}$ & $1.54 \pm 0.19$ & $1.47 \pm 0.25$ & $1.67 \pm 0.22$ \\
$V^{\prime} 50 \quad \mathrm{~L} \cdot \mathrm{s}^{-1}$ & $1.75 \pm 0.21$ & $1.66 \pm 0.26$ & $1.81 \pm 0.23$ \\
$V^{\prime} 25 \mathrm{~L} \cdot \mathrm{s}^{-1}$ & $0.89 \pm 0.12$ & $0.86 \pm 0.16$ & $0.98 \pm 0.14$ \\
\hline
\end{tabular}

Values are presented as mean \pm SEM. No significant changes were observed between the values. FVC: forced vital capacity; FEV1: forced expiratory volume in one second; PEF: peak expiratory flow; MMF: maximum mid-expiratory flow; $V^{\prime} 50$ and $V^{\prime} 25$ : expiratory flow at 50 and $25 \%$ vital capacity, respectively. 


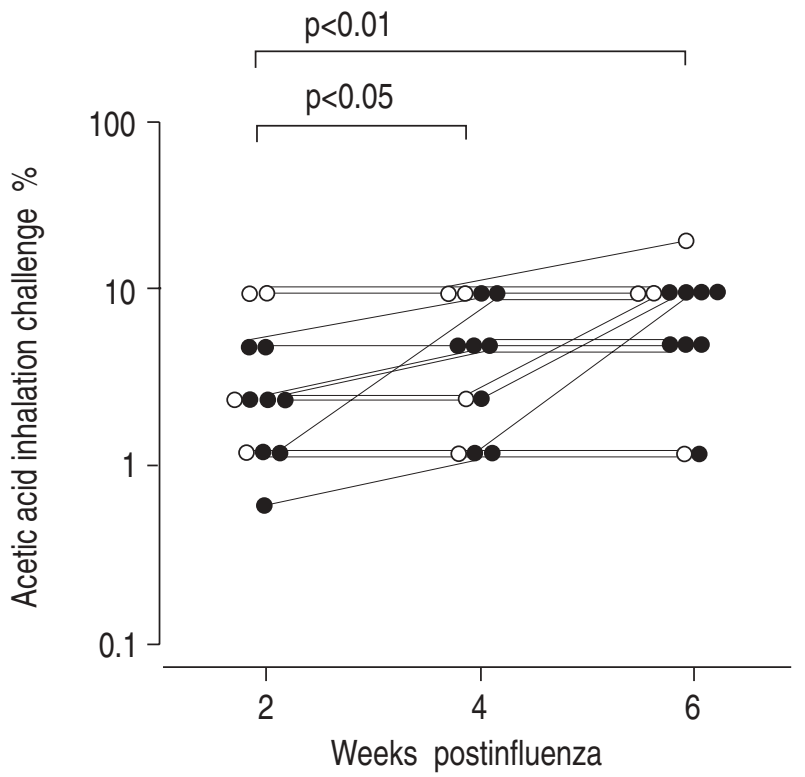

Fig. 1. - Changes in acetic acid (AA)-induced cough threshold values in patients with asthma 2, 4 and 6 weeks after influenza infection. The cough threshold values after 4 or 6 weeks were significantly improved over that at 2 weeks $(\mathrm{p}<0.05$ and $\mathrm{p}<0.01$, respectively). —-— : patients with asthmatic attack; ——_— : patients without attack during the acute illness.

\section{Discussion}

We have shown that naturally-acquired influenza A virus infection in the respiratory tract attenuates the acidinduced cough threshold independently of airway obstruction in children with asthma. The change in cough threshold values seemed to be present both in patients with and without asthmatic attack during the acute illness.

Although this study was not a controlled one, patients enrolled in the study were in-patients living in an institution, and had been hospitalized for a long time (more than 1 year) at the time of the study. The clinical conditions were kept constant before and throughout the study. Thus, the changes in cough threshold values during the study were thought not to be due to seasonal change but to the effect of influenza A virus infection.

It is well-known that viral, including influenza A virus, infections exacerbate asthma, especially in children, with viral infections accounting for $26-42 \%$ of childhood asthma episodes [1-6]. In fact, during high virus prevalence seasons, up to $85 \%$ of childhood asthma exacerbations are associated with viral airway infection [6]. With respect to influenza A virus infection, there have been reports that all affected asthmatic children had exacerbations of their asthmatic symptoms [5, 17], although the percentage of asthma exacerbation in the present study was rather small (67\%). One of the reasons for the low incidence of asthma exacerbation in this study may be differences in the background factors. The patients enrolled in the study were all in-patients, whose asthmatic symptoms had been controlled with medications before they developed influenza infection. Thus, it is suggested that differences in the clinical condition accounted for the low incidence of asthma exacerbation.
The mechanism involved in the exacerbation of asthma due to influenza A virus infection might be associated with the damage caused to the airway epithelium [18, 19]. This may release mediators from the epithelium, expose cholinergic nerve endings, promote the penetration of antigen, remove inhibitory epithelial components, such as epithelial-derived relaxant factor, and reduce epithelial uptake and degradation of mediators [20]. These factors can promote bronchoconstriction and exacerbate asthma.

There have been reports demonstrating increased bronchial hyperresponsiveness after viral infections in humans [7, 8, 21-23]. However, less is known about the effect of viral infection on the cough threshold, with only EMPEY et al. [7] reporting that adult nonasthmatic subjects with colds showed an exaggerated cough threshold to inhaled acid. They suggested that the exaggerated cough response was due to a decreased threshold for stimulation of the rapidly adapting sensory receptors in the airways. It is known that the responsiveness of the rapidly adapting receptors is increased during lung infection in the dog [24].

Cough is a reflex response of the respiratory tract and is produced by inflammatory, mechanical, chemical and thermal stimulation of the cough receptors [25, 26], which are believed to be the fine sensory nerve endings of the trigeminal, glossopharyngeal, superior laryngeal and vagal nerves. It is possible that airway epithelial damage induced by respiratory viral infection exposes and, thus, "sensitizes" the airway cough receptors to inhaled irritants, causing an increased cough threshold.

In the present study, spirometric values of the patients did not change throughout the study. According to the report of JoHANSON et al. [27] on adult patients, the decrease in spirometric values during the acute phase of influenza A virus infection improved after 2 and 6 weeks of illness. There was no statistical difference in the spirometric values 2 and 6 weeks after the illness. With respect to asthmatic children with influenza A virus infection, there have been two reports describing the time-course of FEV1 during the acute phase of illness $[17,28]$. They showed that the decrease in FEV1 became maximal on the first to second day of illness, and returned to within $10 \%$ of the initial value by the tenth day. Our results in the present study are consistent with previous observations.

It was of great interest that influenza A virus infection attenuated the cough threshold without changing the airway calibre. In patients with asthma, cough and bronchoconstriction often occur simultaneously and have been considered to be closely related. However, accumulating data indicate that cough and bronchoconstriction are separate airway reflexes. We have reported that inhaled acid can elicit cough without bronchoconstriction [15], and that airway obstruction does not change the acid-induced cough threshold in children with asthma [29]. The absence of permeant anion (e.g. chloride) in an isosmolar solution causes cough, but not bronchoconstriction [30]. Inhalation of local anaesthetics inhibits cough, but not bronchoconstriction; disodium cromoglycate inhibits bronchoconstriction, but not cough, induced by distilled water [31]. These observations suggest that the mechanisms of cough and bronchoconstriction are related but can be independently triggered. Our study 
result. showing that the cough threshold values in patients with asthma were attenuated after influenza A virus infection without any change in the degree of airway obstruction, further supports the above opinion.

In conclusion, we have demonstrated that naturallyacquired influenza A virus infection attenuates the cough threshold in children with asthma. Further controlled studies are needed to clarify the mechanisms involved.

Acknowledgements: The authors are grateful to K. Tateno and $\mathrm{T}$. Kimura for their kind assistance.

\section{References}

1. Jennings LC, Barns G, Dawson KP. The association of viruses with acute asthma. NZ Med J 1987; 100: 488490.

2. Teo J. Vellayappan K, Yip WCL, Doraisingham S. Mycoplasma pneumoniae and viral infections in childhood asthma. J Trop Pediatr 1986; 32: 87-89.

3. Carlsen KH, Orstavik I, Leegaard J, Hoeg H. Respiratory virus infections and aeroallergens in acute bronchial asthma. Arch Dis Child 1984; 59: 310-315.

4. Horn MEC, Brain EA, Gregg I, Inglis JM, Yealland SJ, Taylor P. Respiratory viral infection and wheezy bronchitis in children. Thorax 1979; 34: 23-28.

5. Minor TE, Dick EC, DeMeo AN, Ouellette JJ, Cohen M, Reed CE. Viruses as precipitants of asthmatic attacks in children. JAMA 1974; 227: 292-298.

6. McIntosh K, Ellis EF, Hoffman LS, Lybass TG, Eller JJ, Fulginiti A. The association of viral and bacterial respiratory infections with exacerbations of wheezing in young asthmatic children. J Pediatr 1973; 82: 578-590.

7. Empey DW, Laitinen LA, Jacobs L, Gold WM, Nadel JA. Mechanisms of bronchial hyperreactivity in normal subjects after upper respiratory tract infection. Am Rev Respir Dis 1976; 113: 131-139.

8. Aquilina AT, Hall WJ, Douglas RG, Utell MJ. Airway reactivity in subjects with viral upper respiratory tract infections: the effects of exercise and cold air. Am Rev Respir Dis 1980; 122: 3-10.

9. Shimizu T, Mochizuki H, Kato M, Shigeta M, Morikawa A, Hori T. Immunoglobulin levels, number of eosinophils in the peripheral blood and bronchial hyperresponsivity in children with Mycoplasma pneumoniae pneumonia. Jpn J Allergol 1991; 40: 21-27.

10. Collier AM, Pimmel RL, Hasselblad C, Clyde WA, Knelson JH, Brooks JG. Spirometric changes in normal children with upper respiratory infections. Am Rev Respir Dis 1978; 117: 47-53.

11. Little JW. Hall WJ, Douglas RG, Mudholkar GS, Speers DM, Patel K. Airway hyperreactivity and peripheral airway dysfunction in influenza A infection. Am Rev Respir Dis 1978; 118: 295-303.

12. Berglund E, Birath G, Bjure J, et al. Spirometric studies in normal subjects. I. Forced expirograms in subjects between 7 and 70 years of age. Acta Med Scand 1963; 173: 185-192.

13. Mochizuki H, Shimizu T, Maeda S, Tokuyama K, Morikawa A, Kuroume T. Relationship between ultrasonically-nebulized distilled water-induced bronchoconstriction and acid-induced cough in asthmatic children. J Allergy Clin Immunol 1995; 96: 193-199.
14. Mochizuki H, Shimizu T, Morikawa A, Kuroume T. Inhaled diuretics attenuate acid-induced cough in children with asthma. Chest 1995; 107: 413-417.

15. Mitsuhashi M, Mochizuki H, Tokuyama K, Morikawa A, Kuroume T. Hyperresponsiveness of cough receptors in patients with bronchial asthma. Pediatrics 1985; 75: 855-858.

16. Mitsuhashi M, Tokuyama K, Morikawa A, Kuroume T, Tazawa M. Does disodium cromoglycate stabilize cough receptors on human airways? (Letter). Lancet 1984; i: 576.

17. Roldaan AC, Masural N. Viral respiratory infections in asthmatic children staying in a mountain resort. Eur $J$ Respir Dis 1982; 63: 140-150.

18. Hers JF. Disturbances of the ciliated epithelium due to influenza virus. Am Rev Respir Dis 1966; 93: 162-171.

19. Soderberg M, Hellstrom S, Lundgren R, Bergh A. Bronchial epithelium in humans recently recovering from respiratory infections caused by influenza or Mycoplasma. Eur Respir J 1990; 3: 1023-1028.

20. Barnes PJ. New concepts in the pathogenesis of bronchial hyperresponsiveness and asthma. J Allergy Clin Immunol 1989; 83 1-10.

21. Jenkins CR, Breslin ABX. Upper respiratory infections and airway reactivity in normal and asthmatic subjects. Am Rev Respir Dis 1984; 130: 879-883.

22. Laitinen LA, Elkin RB, Empey DW, Jacobs L, Mills J, Nadel A. Bronchial hyperresponsiveness in normal subjects during attenuated influenza virus infection. Am Rev Respir Dis 1991; 143: 358-361.

23. Lamanske RF, Dick EC, Swenson CA, Vrtis RF. Rhinovirus upper respiratory infection increases airway hyperreactivity and late asthmatic reactions. $J$ Clin Invest 1989; 83: 1-10.

24. Dixon M, Jakson DM, Richards IM. The effect of a respiratory tract infection on histamine-induced changes in lung mechanics and irritant receptor discharge in dogs. Am Rev Respir Dis 1979; 120: 843-848.

25. Coleridge JCG, Coleridge HM. Afferent vagal C fibre innervation of lungs and airways and its functional significance. Rev Physiol Biochem Pharmacol 1984; 99: $1-110$.

26. Sant'Ambrogio G. Afferent pathways for the cough reflex. Bull Eur Physiopathol Respir 1987; 23(Suppl. 10): $19 \mathrm{~s}-24 \mathrm{~s}$.

27. Johanson WG, Pierce AK, Sanford JP. Pulmonary function in uncomplicated influenza. Am Rev Respir Dis 1969; 100: 141-147.

28. Kondo S, Abe K. The effect of influenza virus infection on FEV1 in asthmatic children: the time course study. Chest 1991; 100: 1235-1238.

29. Shimizu T, Mochizuki H, Tokuyama K, Morikawa A. The relationship of the acid-induced cough response and airway responsiveness and obstruction in children with asthma. Thorax 1996; 51: 284-287.

30. Eschenbacher WL, Boushey HA. Sheppard D. Alteration in osmolarity of inhaled aerosols cause bronchoconstriction and cough, but absence of a permeant anion causes cough alone. Am Rev Respir Dis 1984; 129: 211-215.

31. Sheppard D, Rizk NW, Boushey HA, Bethel RA. Mechanism of cough and bronchoconstriction induced by distilled water aerosol. Am Rev Respir Dis 1983; 127 : 691-694. 